\title{
A HISTORY OF MILITARY NOMENCLATURE IN SOUTH AFRICA
}

\author{
N.M. COWLING*
}

\section{INTRODUCTION}

Military nomenclature is an important dimension of military culture and receives a high profile in some armed forces, while in others it is a relatively low priority. In South Africa nomenclature played a very understated role for a long period but was accorded a higher degree of importance over the past fifty years. In order to understand the motivation and pattern of the trends in military nomenclature in South Africa, it is essential to acquaint oneself with the policy of the South African Defence Force which has regulated and determined the provision of names since 1912. Although the history of nomenclature in the Defence Force touches on politically sensitive issues, one should to bear in mind that, like most things, the provision of names and titles does not take place inside a vacuum. The nomenclature policy has therefore always been susceptible to the political climate, which has often determined the direction it has taken in South Africa over the past eighty years.

The history of nomenclature in the SADF is not as well documented and clear cut as one would like it to be. This situation is due to two factors. Firstly, there is a shortage of both published and archival sources; and secondly, the fact that a written and set policy was only compiled and issued by the Defence Force for the first time in 1984. As a result of these drawbacks, research on the subject is both time consuming and difficult. The aim of this paper is to outline the trends of military nomenclature in South Africa since 1912 and to discuss the metamorphosis of the nomenclature policy currently in use within the SADF. In order to ascertain a complete picture of military nomenclature in South Africa, it is also necessary to discuss the impact which the British Army and other military forces made on South African nomenclature. It is advisable to discuss the influence of British traditions if one is to determine whether or not the guardians of nomenclature in South Africa managed to distance it from these roots and assume a predominantly South African orientation. Research on points such as these will eventually help to outline the true tradition of nomenclature in the SADF.

\section{2-1947 THE UNION DEFENCE FORCE}

With the establishment of the Union Defence Forces (UDF) in 1912, two military traditions - those of the British Army and the armed forces of the Boer Republics - were united, although the British tradition remained dominant in the UDF. When the UDF was formed in 1912 under the South African Defence Act (No. 13 of 1912), it was small and consisted mainly of Active Citizen Force units with a small Permanent Force staff. The need for a nomenclature policy was almost non-existent as most of these units, and the buildings they were stationed in, already had names. There was also no need for the naming of armaments, vehicles or vessels as these were usually manufactured outside South Africa. Whatever the nomenclature policy was which the UDF applied prior to World War One, it appears to have been based upon the name provision principles of the British armed forces. Nomenclature in the British Army was a relativley simple process whereby a regiment was named after the district in which it was raised. After receiving a geographical and numerical designation regiments were then accorded either a functional title or a royal title or both. For Example : The Queen's Own Cameron Highlanders or the Somerset Light Infantry (Prince Albert's).' 
In South Africa, prior to 1910, the British colonial secretary, Lord Elgin, conveyed the necessary instructions from the King concerning regimental titles and distinctions to the Army. These procedures, which were prescribed at a time when South African units had been linked to the British Army, were identical to the ones later followed in the UDF. ${ }^{2}$ This instant British recipe inherited by the UDF, obviously reduced the need for the creation of a new nomenclature policy in South Africa, and as a result not much was done to construct one. If an application for a name was necessary, the function appears to have been handled by the office of the Adjudant General, who did all the necessary administrative work, before sending it to the Chief of the General Staff for approval. ${ }^{3}$

When World War One broke out, the UDF had only been in existence for two years and was hard pressed to mobilise and prepare for war in the time available. The resulting situation meant that nomenclature was put onto the back burner as the more pressing priorities

of war came to the fore. As a result any nomenclature policy which might have been in the pipeline was shelved. During World War One a number of units were raised in order to bring brigades up to full strengh but the UDF did not go to a great deal of trouble to find fitting names for them. Instead the
Army followed the traditional policy of naming regiments by incorporating their geographical and functional details. ${ }^{4}$ For example : the 7th District Rifles established in 1914 were named the "De Hoogeveld Schutters" and the 9th Infantry established in 1917 were called "The Peninsula Rifles". ${ }^{5}$ This method of naming units had started during the previous century with the Volunteer Settler regiments and Boer Commandos. The senior officers in the UDF apparently considered this to be a good system and applied it with gusto to almost all the new units that were

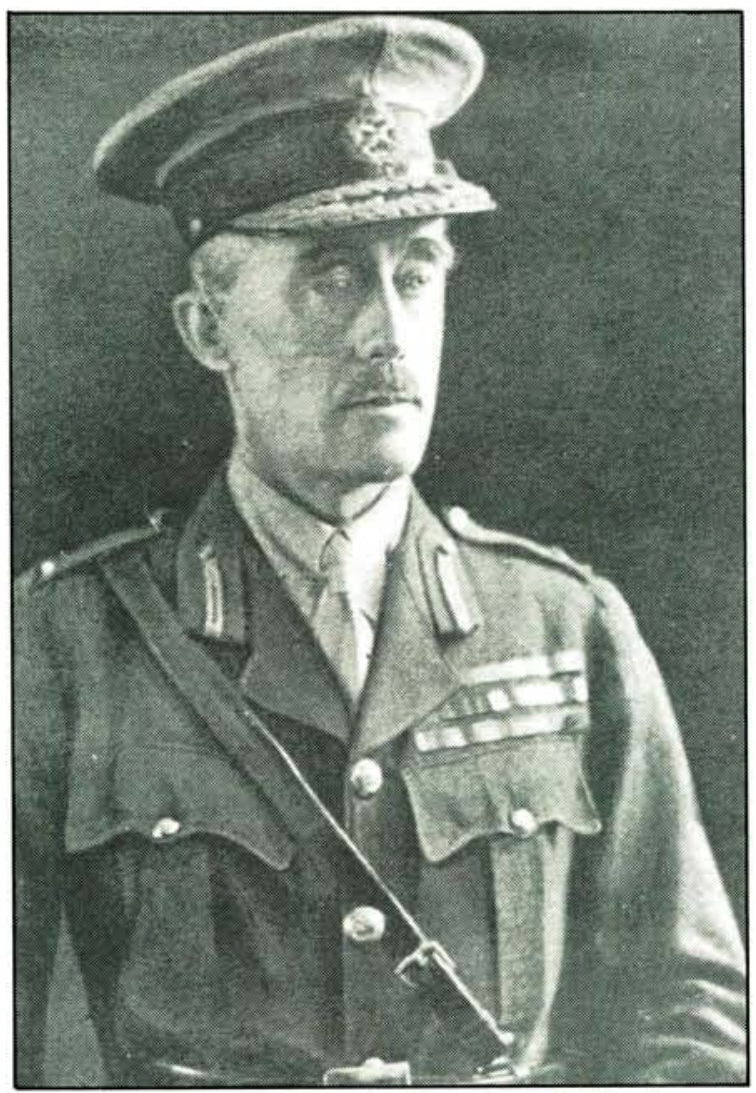

Brigadier General J.J. Collyer, Chief of Defence Staff.

formed. Regiments in existence prior to the founding of the UDF were allowed to keep their original titles. However, notable exceptions in this case are the official units and corps of the former ZAR and OVS republics. These were $a b$ sorbed straight into existing UDF regiments and, as a result, lost their titles and often their original functions. The Staatsartillerie of the two Boer Republics provide a good example. both were $a b$ sorbed into the South African Mounted Rifles. ${ }^{\circ}$

Following World War One, the UDF underwent a process of rationalisation, while at the same time establishing the South African Air Force (SAAF) and the South African Naval Service (SANS) in 1923. ${ }^{7}$ Despite the fact that these new services must have created a growing need for a nomenclature policy, noth-

2 Archive of the Secretary for Defence (hereafter DC). Box 27. File DC 549 Honorary Distinctions and Titles to Estabilished Units. Minute dd 26 April 1907, Lord Elgin to Lord Knutsford.

3 Col. J.A. Combrinck and L. Jooste: Beleid van Naamgewing in die SAW (Annual of the Names Society SADF 1991), p.23.

4 Maj T.J. Edwards : Regimental titles (Army Quarterly and Defence Review, vol XXVII, No 1, October 1933), p.58-71.

5 DC. Box 27. File 594 Honorary distinctions and Titles to Estabilished Units. Minute dd 28 July 1914. Prime Ministers office to the Secretary of Defence for the Minister of Defence; and DC. Box 148. File 5397. Establishment of the 9th Infantry. Minute A/5397/A dd 21 June 1917, Adjudant General to Quartermaster General.

- DC. Box 180, File 8468 Absorption of the Staatsartillerie (ZAR \& OVS), dd 12 May 1914. G.N. 17 of 1923 (Government Gazette No 1289 dd 26 January 1923). 
ing concerning the formulation of such a statement appears to have been done. A possible explanation for this lack of action may be the continuing rationalisation. From 1922, the UDF was cut and reorganised annually and when the Great Depression started in 1929, even the Active Citizen Force (ACF) units were disbanded. Whether there was actually a need for a nomenclature policy at that stage, or indeed, anyone to execute it, is questionable. When a slow rebuilding of the UDF did occur in the late 1930s, it involved the re-establishment of defunct units and, as a result, there was still no pressing void regarding name provision which anyone felt obliged to fill. The primary military name change of the decade did not even originate from within the UDF, but was, in fact, instigated by the Minister of the Interior in 1938. The occasion arose during the Great Trek centenary celebrations when Roberts Heights was renamed Voortrekker-hoogte. Even then, the Post Office did not change the name of its depot in the Heights until it was ordered to do so in 1948. ${ }^{8}$ The confusion that this caused explains why, in later years, military name changes were co-ordinated with the National Place Names Committee.

By the onset of World War Two, the situation had changed slightly, and the UDF was moving towards a more modern method of naming units. Those established in the 1930s were seldom accorded long elaborate designations. Instead, their names were functional and brief, such as the 7th Field Ambulance SAMC or Regiment Botha. ${ }^{9}$ The new trend was a result of the UDF reorganisation during the late 1930s, when a decision appears to have been taken to simplify the numbering system after the brigade group areas had been redivided. ${ }^{10}$ On the administrative side, the only change made was the transfer of the approval function to the Deputy Chief of Staff as the Chief of the General Staff was fully occupied with urgent war matters. ${ }^{11}$

Although the new numerical system became widespread across the globe, it should be pointed out that at the termination of hostilities units usually reverted back to their old names. The reason for this being that most of the serving units in the UDF were intensely proud of both their regimental traditions and their individuality. Furthermore, most of them had affiliations with British and Commonwealth regiments. ${ }^{12}$ Any UDF policy which could have interfered with the regimental situation was consequently viewed as unfavourable as it would have caused a huge outcry from the ACF and overseas regiments which maintained South African connections. The UDF could not afford to create dissatisfaction where the ACF was concerned, as the Force constituted the bulk of the Army's strength and the Defence hierarchy was still keenly aware that it was reliant on the services and goodwill of volunteers in the event of trouble. Nevertheless by this stage, a fledgling nomenclature policy had begun to take root.

Following the end of World War Two and the subsequent demobilisation and rationalisation of the UDF, the administration and organisation of the Defence Force improved dramatically. This led to name provision being placed on a firmer footing as a new procedure for nomenclature was outlined. The new directions applying to name provision which had been formulated were finally that prospective names had to be appropriate and not already in use within the UDF. The overriding consideration as far as names were concerned, was that they should increase the esprit de corps of a unit. ${ }^{13}$ It would not be long, however, before the UDF and most policies concerning the armed services in South Africa were to change drastically.

D.W. Kruger : The making of a nation, a history of the Union of South Africa (Johannesburg 1969), p. 192.

Archive of the Adjudant General (hereafter AG 3), Box 190, File 369/1/9 Circular dd 23 October 1934, Office of the Adjudant General; and Archive of the General Officer Commanding, Union Defence Force (hereafter GOC), Box 5 , File 49/1 Circular dd 29 August 1934, Office of the Adjudant General.

10 GOC, Box 5, File 49/1 Circular dd 11 May 1935, Officer Department of Defence to Officer Commanding Brigade Sections.

11 Col J.A. Combrinck and L. Jooste : Beleid van Naamgewing in die SAW (Annual of the Names Society SADF 1991), p.23.

$12 \mathrm{AG}(3)$, Box 133, File 47/1 Minute A/ADM/12 dd 25 February 1958, Adjudant General to Officer Commanding Wits Command.

13 Col J.A. Combrinck and L. Jooste: Beleid van Naamgewing in die SAW (Annual of the Names Society SADF 1991), p.24. 


\section{THE POST WAR UNION DEFENCE FORCE 1948-1957}

Shortly after the Second World War, the National Party came to power by winning the 1948 general election. The history of the armed services in the period after the Nationalist takeover is mostly controversial. Some people view it as a time of very positive developments in the UDF, while others believe that some of the developments were counterproductive. ${ }^{14}$ It was no secret that many senior officers in the UDF had always been strong supporters of General Smuts and the United Party: and as a result, the Defence Force was viewed as a target for change, in order to bring it more into line with the aims and ideals of the new government.

One of the areas in which changes were made, was in the composition and nature of military name provision; this was primarily due to the fact that there were those who

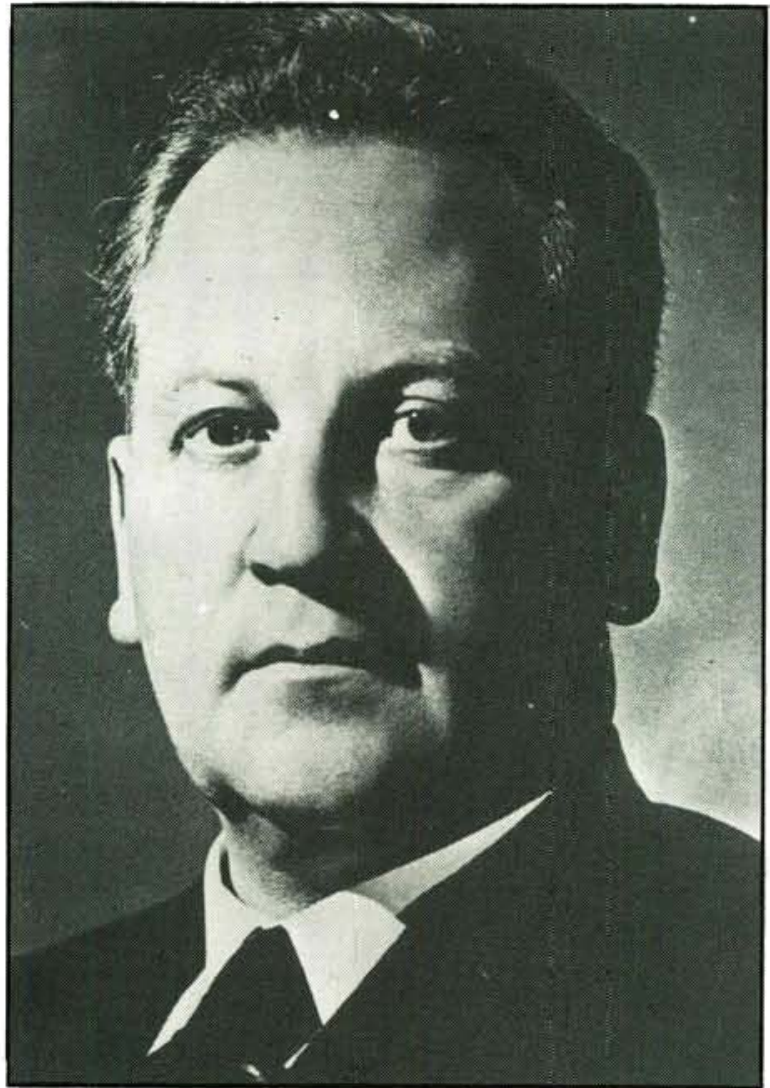

Adv F.C. Erasmus, the first Nationalist Minister of Defence.
Erasmus was determined to establish a South African character in the UDF. During this process, especially during the period 1948-1955, he introduced several far-reaching changes into the Defence Force. It was thus not very long before the new nomenclature policy received a thorough test run and many prestigious old units were threatened with extinction at one time or another (these units were both English and Afrikaans medium). The cause of the rash of changes during the late fifties was twofold. Firstly the reorganisation of the $\mathrm{De}$ fence Force necessitated structural adjustments while secondly, there was a conscious effort on the part of some people to rid the UDF of any characteristics which were obviously British in orientation. This naturally included the names of certain regiments.

The reorganisation of the UDF included the expansion of were of the opinion that the UDF was too anglicised and that some sort of a language balance had to be achieved. One of the obvious ways in which to achieve such an objective was to review the UDFs nomenclature policy; and it consequently was not much of a surprise that the new Minister of Defence, F.C. Erasmus, took such a personal interest in the creation of a nomenclature policy. Erasmus recognised the importance of names in the UDF, far more so than any of his predeccesors had done and played a the Citizen Force, something which greatly affected regimental titles. Erasmus decided to admit the old Commando units to the UDF as fully fledged Citizen Force units and this created problems as far as the duplication of names was concerned. 16 Many of the Commandos integrated into the Defence Force had identical designations to some of the Afrikaans medium regiments, and, much to the chagrin of the older units, it was them, not the Commandos who had to replace their regimental titles. This deci-

14 E.P. Hartshorn: Avenge Tobruk (Cape Town 1960), pp. 207-225; and J. Barber and J. Barratt : South Africas Foreign PolicyThe search for status and security 1945-1988 (Johannesburg 1990), p.58.

15 Col J.A. Combrinck and L. Jooste: Beleid van Naamgewing in die SAW (Annual of the Names Society SADF 1991), p.24. 
sion was not only perceived as being highly unfair, but the units were further angered by the new names allotted to them. Most of the new regimental names had a geographical origin as in the examples shown below.
In the long term, most of the units enjoyed moderate success in re-acquiring their original names in view of the protests received by the Commandant General of the SADF. The argument against the geographical names was

\section{Original Title}

Regiment De La Rey

Regiment Gideon Scheepers

Regiment Hendrik Potgieter

\section{New Title}

Regiment Wes Transvaal

Regiment Groot Karoo Regiment Mooirivier
Understandably members of these units felt that Erasmus was trying to curry favour with the Commandos, as he had not only allowed them, as newcomers, to keep their names but the new names chosen for the regiments were uninspiring and unwanted. ${ }^{17}$

Initially English medium units did not suffer the same fate, although in later years many of the regimental titles would be altered. Generally the criterion applied when naming a unit was based on the home language of the majority of the members of the unit. During this period there were only a few English medium units which had their names changed, the most notable being the Cape Field Artillery which became Regiment Tygerberg. ${ }^{18}$ However, certain units became increasingly isolated because of their foreign names and customs, which were viewed unfavourably in the Defence Force after the Nationalist takeover. Many regiments also lost their affiliations to overseas units as the Minister of Defence was no longer prepared to allow more ties to be renewed. ${ }^{19}$ One result of the discontinuation of the affiliation system, was that English medium units had less of an excuse to hold on to British customs and names and many of them consequently found themselves becoming the victims of enforced titular changes in years to come. ${ }^{20}$ that they had created a lack of tradition and esprit de corps. ${ }^{21}$ Although most people viewed this specific excercise as a complete waste of time on Erasmus' part, the unsuccessful name changes had at least one positive side effect, namely, that the name provision process would no longer be unilateral but would from then on be conducted by liaising with all the parties concerned in an effort to satisfy all aspirations as far as possible.

A further development during this period which was to have far-reaching effects was the new Defence Act which was passed by Parliament in 1957. This Act laid the foundation on which the SADF is currently based and also gave rise to a period of extended growth for the Military. Two other important aspects of the new law were the transfer of Simonstown Naval Base from Britain to South Africa and the changing of the Defence Force's name from the Union Defence Force to the South African Defence Force on December 1, 1957. These changes heralded the dawn of a new era for the SADF and subsequently for those who bore responsibility for the nomenclature programme. ${ }^{22}$

\section{8-1975 EXPANSION AND MODERNISATION}

South Africa became a republic on 31

\footnotetext{
DC (GP 3), Box 180, File 823/1/2 Further Defence Amendment Bill dd 19 April 1961. Act No. 44 of 1957. E.P. Hartshorn: Avenge Tobruk (Durban 1968), p.218.

18 Archive of the Minister of Defence-Botha Collection (hereafter MVB), Box 152, Memorandum dd 10 June 1966, Name changes in the Citizen Force in 1959/1960.

19 AG (3), Box 133, File 47/1 Minute HGS 675 dd 21 January 1957, Chief of the General Staff to the Adjudant General; and AG (3), Box 47, Minute dd 31 January 1959 to Army Chief of Staff.

20 AG (3), Box 133, File 47/1 Minute dd 31 March 1958, Adjudant General to Commandant General; and AG (3), Box 133, File 47/1 Minute dd 31 January 1959. Adjudant General to Army Chief of Staff.

${ }_{21}$ MVB, Box 152, Memorndum dd 10 June 1966, Cabinet Sub-committee memorandum.

22 J. Barber and J. Barratt : South Africa's Foreign Policy, (Johannesburg; 1990), p.58.
} 


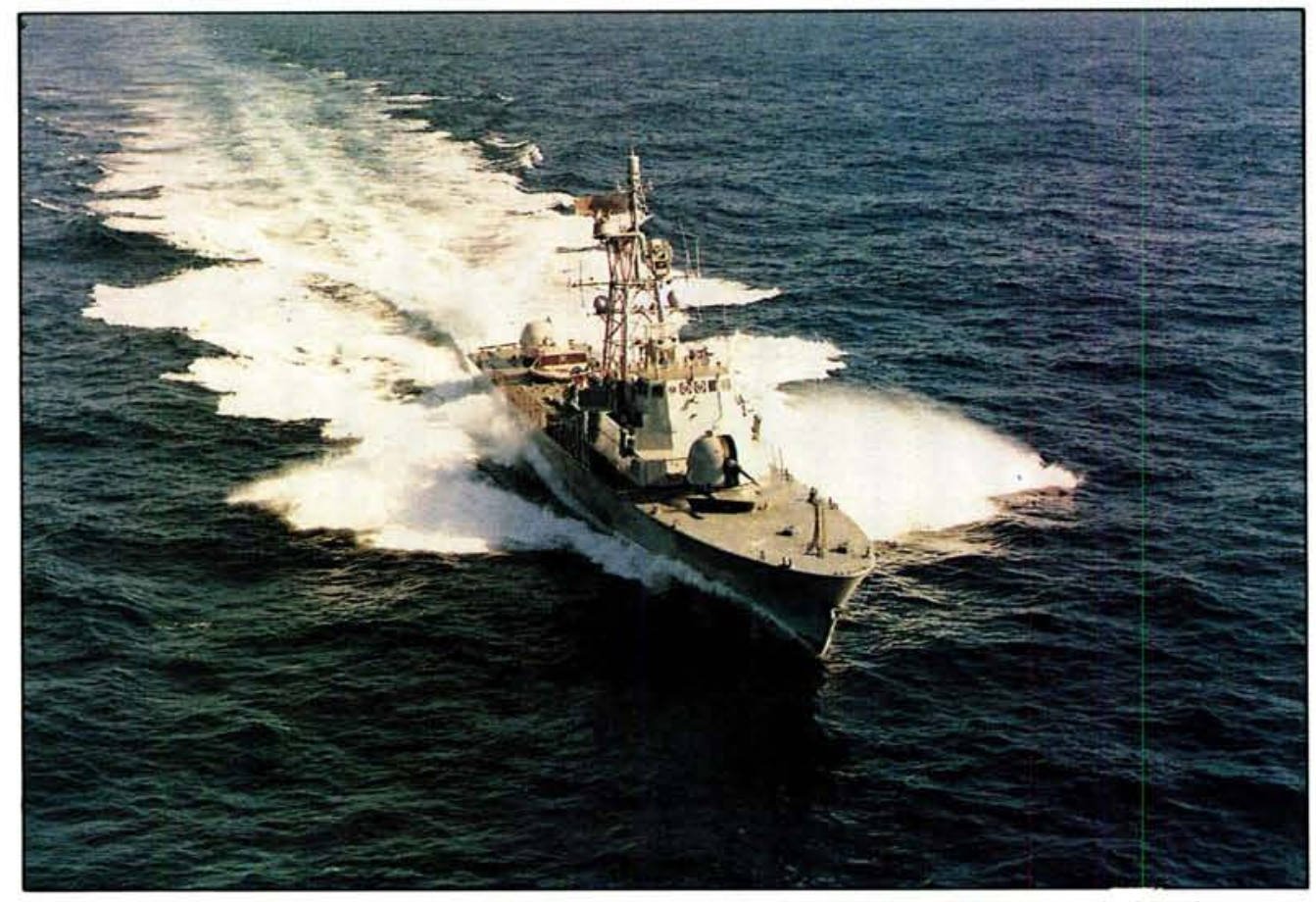

The SA Navy Strike Craft are named after previous South African Ministers of Defence.

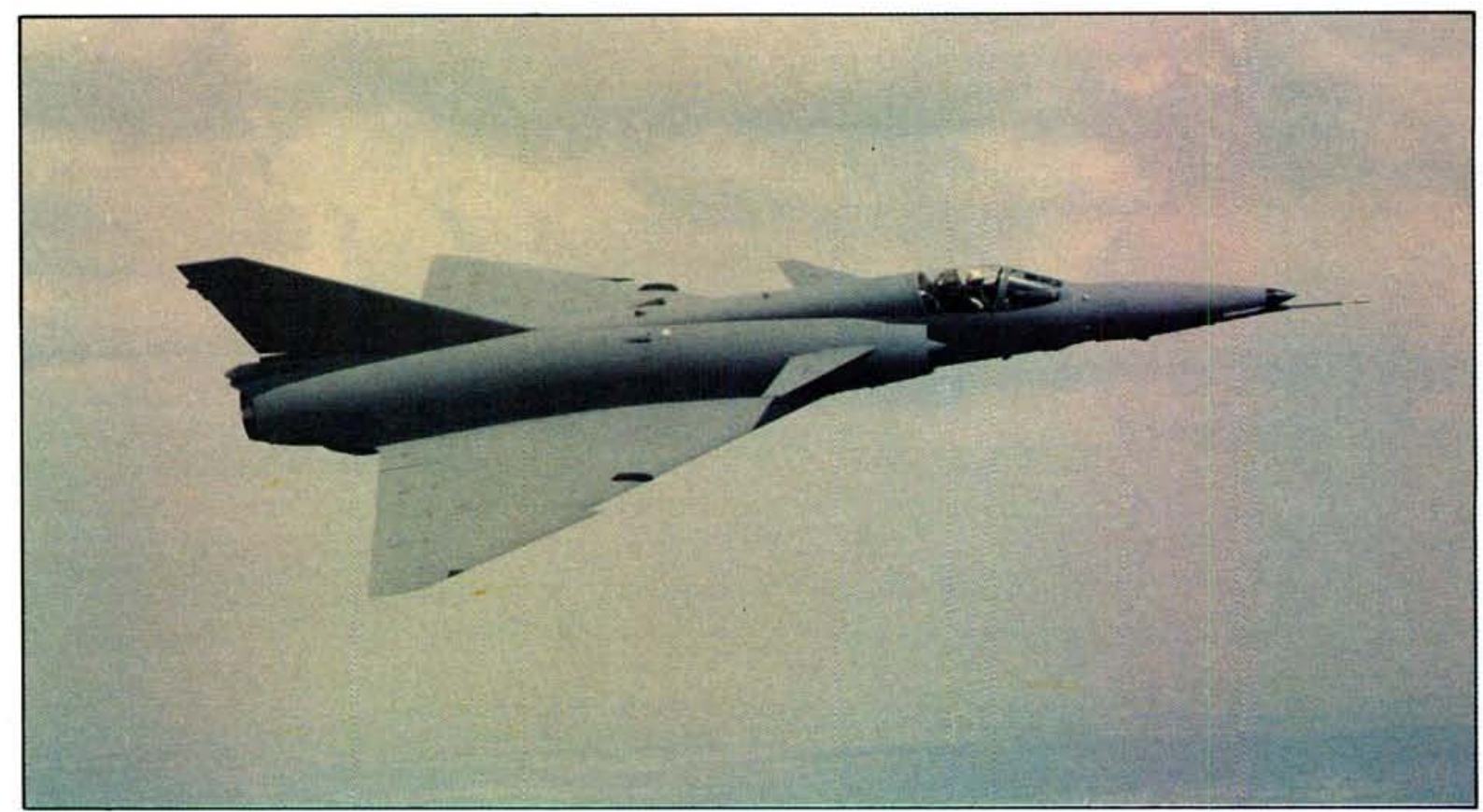

The SAAF Cheetah. Usually aircraft are named after birds or antelope. 


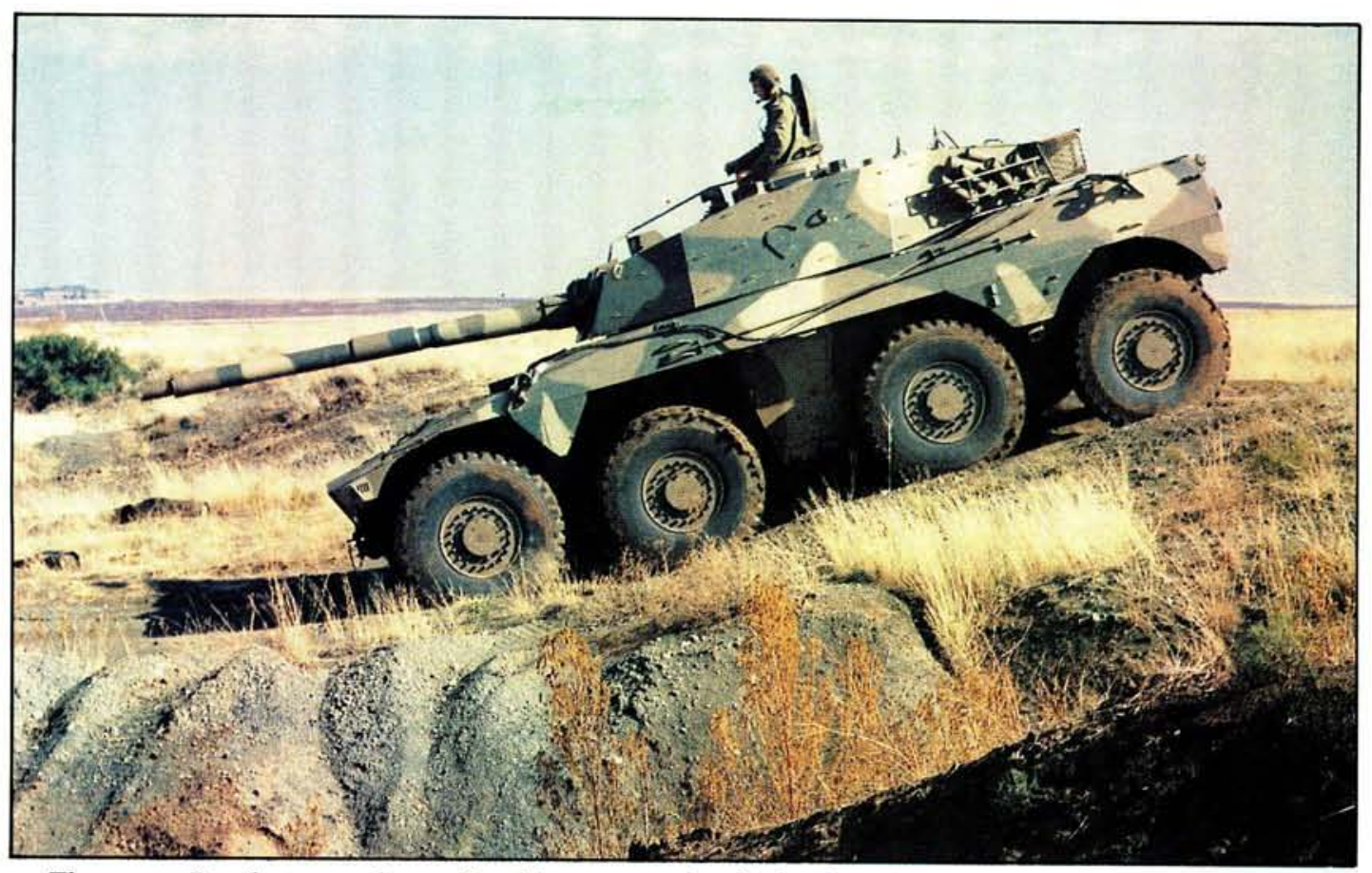

The name Rooikat was chosen for this armoured vehicle after the Army's application to name it Cheetah was turned down.

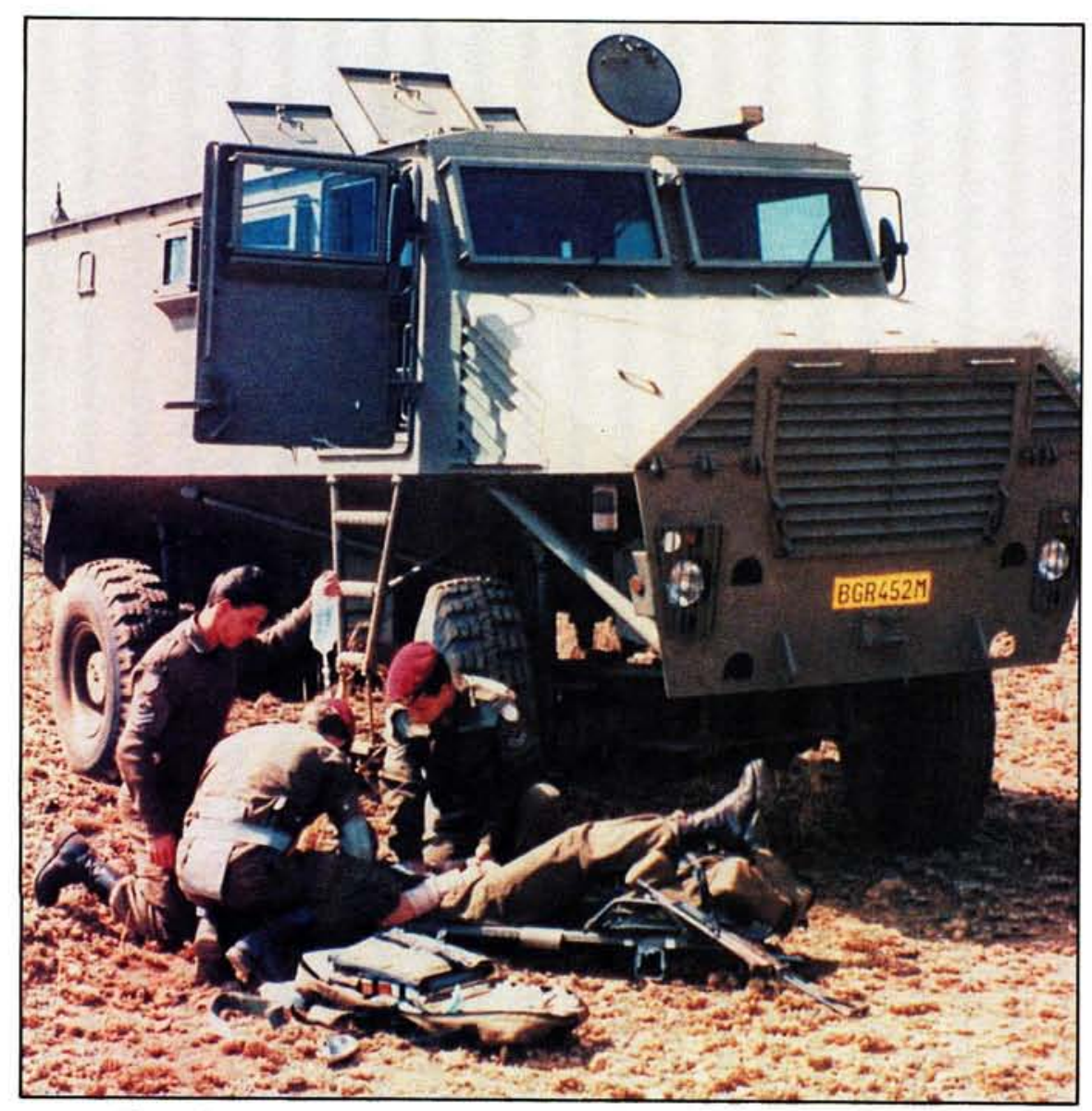

The Mfezi is a mine protected ambulance in service with the SAMS. 
May 1961, and withdrew from the British Commonwealth later in that year. The ensuing developments brought a myriad of changes although they were probably quite different to what Harold Macmillan had envisaged when he made his famous "Winds of Change" speech in Cape Town a few months earlier. ${ }^{23}$ The country's new republican status brought with it a new system and new values, which did not revolve around Britain. Naturally certain English medium units were affected by the new political situation, as the nomenclature programme had to be adjusted to ensure that it remained politically correct, within the country's new republican system.

Most of South Africa's renowned volunteer regiments had connections with the British Monarchy through their regimental titles, and as soon as the transition from Union to Republic was complete, the respective units were ordered to drop any regal inflections from their names. Despite the fact that some of the regiments concerned managed to procrastinate for some months in an attempt to avoid the inevitable, all the necessary changes were made by the end of 1961. ${ }^{24}$

A few examples of the regiments which were involved are: growth of the SADF ensured that what remained was so limited that it became insignificant. The SADFs reorganisation and expansion in the 1960s resulted in further developments in the nomenclature policy. A system of compulsory National Service for all White males, initially lasting the duration of one year, was introduced in 1968. This naturally increased the size of the Force quite considerably and, as a result, additional bases and training grounds had to be built to accommodate the new troops. These developments had repercussions which affected the outdated military nomenclature policy. Consequently those responsible for nomenclature were struggling to function effectively given the additional new workload. The situation was further compounded by the worsening security situation outside the Republic's borders. South Africa became embroiled in a low intensity war in SWA/Namibia, a war which would endure for almost two decades. ${ }^{26}$ The border war further increased the pressure on the staff responsible for the name provision portfolio. They had to contend with a policy based upon a structure which had been designed for a small peace time military.

The sudden spate of military growth in the late 1960s and early 1970s meant

\section{Union}

The Royal Natal Carbineers

The Imperial Light Horse

The Duke of Edinburgh's Own Rifles

The Queen's Own Cape Town Highlanders
Republic

Natal Carbineers

Light Horse Regiment

Cape Town Rifles

Cape Town Highlanders
The Minister of Defence personally approved these changes, although a further application had to be made to the British Monarchy for permission to have all the Royal titles removed from the names. ${ }^{25}$ These changes ushered in a new era for the nomenclature programme in the SADF. Suddenly the Military had been purged of the remaining vestiges of British colonialism as far as possible, and the future that it was no longer only units which had to be named but buildings, bases, training centres and streets as well. The overriding consideration when appointing names remained their effect on unit pride and morale. ${ }^{27}$ Practical needs, however, demanded that the SADFs policy on nomenclature be expanded and adjusted to enable it to adapt to the new and greater demands being made upon it. A new

23 J. Barber and J. Barratt : South Africas Foreign Policy (Johannesburg 1990), pp.66-83.

24 MVB, Box 152, Defence Memorandum dd 10 June 1966. Memorandum on the name changes of Citizen Force Units in $1959 / 1960$

25 Archive of the Chief of the Army General Staff, Artskool, Box 153, File G/SD/13/4/1 Circular dd 7 July 1961, Commandos, Unit Colours, Flags and Badges.

26 H.R. Heitman and P. Hannon: Modern African Wars - South West Africa (London 1991), p.5-13.

${ }_{27}$ Col J.A. Combrinck and L. Jooste : Beleid van Naamgewing in die SAW (Annual of the Names Society SADF 1991), P.26. 


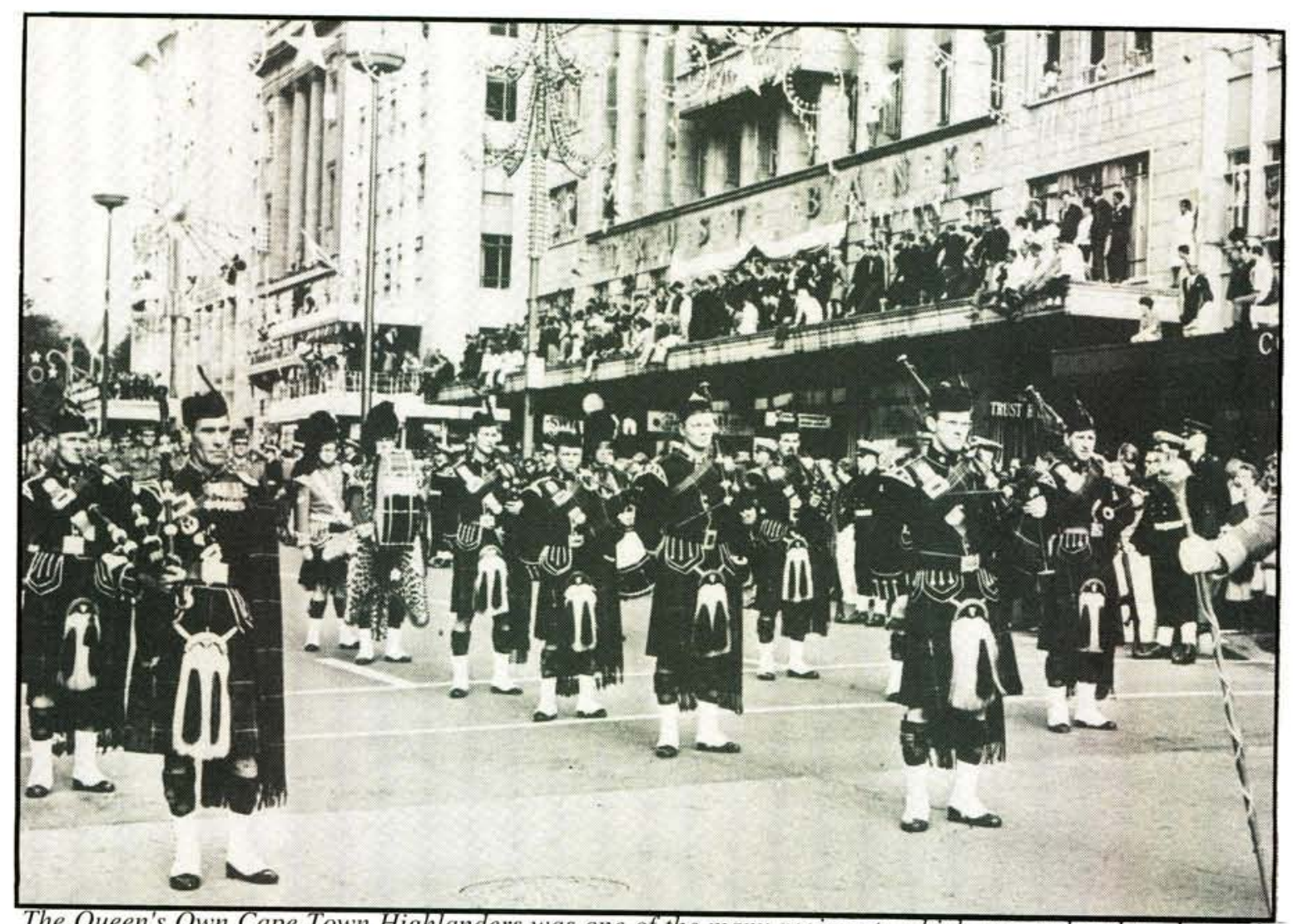

The Queen's Own Cape Town Highlanders was one of the many regiments which was ordered to change its name in 1961, when South Africa became a republic.

addition to the policy was the categorising of names in order to prevent duplication and maintain consistency. In other words, categories were set up from where names could be chosen, but each category was reserved for a different purpose. For example, one could not select a name for a ship from a category earmarked for submarines and so forth. Themes and not the names themselves, were provided in the categories so as to allow for a certain measure of flexibility. For instance the SA Navy's Strike Craft may be named after previous ministers of defence.

As in the days of the UDF, Section Personnel was made responsible for the administration and co-ordination of the programme in 1974. The office of the Minister of Defence continued to remain involved as they authorised the naming of units, bases and training centres while the office of the Quartermaster General was also drawn into the process as it was responsible for naming buildings and streets. This rather decentralised system, was re- placed in April 1974 when the four arm staff structure was introduced into the SADF. The responsiblity for the entire nomenclature programme was then transferred to Chief of Staff Logistics. ${ }^{28}$

Although a need for firmer guidelines and a set policy continued to exist, the nomenclature programme proved easier to administrate once it was coordinated by one section. This situation was aggravated by the escalation of the Border War, as South Africa began to mount cross-border raids into Angola in order to combat the increased guerilla activity in that country. ${ }^{29}$ This became evident through SWAPO infiltration into SWA/Namibia and attacks on the local population. As the war escalated, so too did the size and needs of the SADF and Chief of Staff Logistics was hard pressed to ensure that the nomenclature programme functioned efficiently. For those involved with name provision, it became clear that even further adjustments and advances, in addition to those recently added, would have to be made if the portfolio was to be

28 ColJ.A. Combrinck and L. Jooste: Beleid van Naamgewing in die SAW (Annual of the Names Society SADF 1991), p.26. 29 H.R. Heitman and P. Hannon: Modern African Wars (London 1991), p.7. 
managed in an orderly fashion. This belief was increasingly justified in the long term, as the Border War continued to intensify and South Africa embarked on its first venture into the realm of advanced weapons production.

\section{6-1989 - THE ARMSCOR ERA}

In the latter half of the 1970s, South Africa faced a worsening security scenario, both internally and externally. and by 1976 the Defence Force was once again preparing to expand. Chief of Staff Logistics, which already had a problem administrating name provision efficiently at its current levels, decided to make the name provision task easier and more regulated. The fruits of the logisticians labour appeared in 1977 in the form of a South African Defence Force Order (SADFO) entitled "A policy in connection with the naming of buildings and streets inside military areas", 30 Although a great deal of effort had been put in to the name provision portfolio in the years after 1950 this SADFO was the first policy statement ever written for name provision. The issue of the SADFO provided nomenclature with an official status and placed the programme on a sounder footing. Unfortunatley the policy in itself was rather limited and it was primarily concerned with the naming of buildings and streets. Ironically, these two areas did not even feature in name provision during the days of the UDF and early SADF. Chief of Staff Logistics had based the new policy on the 1967 Defence Force Order that military areas had to be named after South African military figures from the period prior to 1945. As in previous nomenclature orders, the guidelines in the SADFO instructed that duplication had to be avoided, but added that so too did names which could be of potential embarrassment to the Defence Force. $^{31}$ Unfortunately for the architects of this policy, it was not long before the speed of developments in the
SADF made the 1977 SADFO redundant.

Two important organisational changes in the Defence Force in 1979 took the Military to its highest strength ever. thereby creating an immediate need and use for the new nomenclature policy. In January 1978, National Service was increased from a period of one year to two years: and in July of the following year, a fourth arm of service the South African Medical Service (SAMS) - was added to the Defence Force. ${ }^{32}$ A weakness which soon became apparent was that the 1977 nomenclature policy had failed to incorporate military areas into its guidelines. The solution to this problem was presented almost immediately with the issue of a Policy Directive from the Chief of the SADF entitled "Name provision for military areas, buildings and streets", which specifically addressed the existing gaps of the previous policy. ${ }^{33}$ it would not be long however. before the policy had to be updated yet again, this time in order to incorporate weaponry.

The Armaments Corporation of South Africa (Armscor) was established in 1976, in an effort to ensure that South Africa was not left defenceless by the mandatory 1977 Arms Embargo, imposed by the United Nations. ${ }^{34}$ Once full time production was under way. Armscor not only gave South African industry a shot in the arm, but produced a formidable range of high quality weapons and vehicles which were uniquely suited to the SADFs operational requirements. ${ }^{35}$ As most of Armscor's products were manufactured under contract to the SADF, responsibility for naming Armscor's products fell to the Defence Force. Initially, a written directive concerning the arms nomenclature policy did not exist. Instead the responsibility for naming products fell to the different arms of service and was not co-ordinated through Chief of

10 South African Defence Order (SADFO) 4/4/77, HSL/3/22/2. Beleid ten opsigte van naamgewing van geboue en strate binne militre gebiede.

SADFO 4/4/77. HSL/3/22/2. Beleid t.o.v. naamgewing van geboue en strate in militere gebiede

32 Maj Gen D.P. Knobel : Die huidige Uniform, Kentekens en Vaandel van die Suid Afrikaanse Geneeskundige Diens, in Militere Geneeskunde in Suid Afrika 1913-1918. (Pretoria: 1983).pg. 109.

CSADFPolicy Directive 4/35/79. (HSL/401/1/3/4 dd 31 October 1979), Naamgewing aan die Militere gebiede en strate.

4. J. Barber and J. Barratt : South Africa's Foreign Policy (Johannesburg 1990), p.335: and R.H. Heitman : South African Arms and Armour (Cape Town 1988), p. 14.

is C. Bishop and I. Drury: The encyclopedia of military power (London 1988), pp. 68,98,148,266,304. 
Staff Logistics. While this system allowed for flexibility and choice, in the long term it led to confusion and competition.

By 1983 problems had begun to emerge. Occasionally a name would be proposed which did not fall into the suggested category for that particular type of product. This invariably led to a problem as a conflict of interests would arise. A case in point is the incident over the use of the name Cheetah. The South African Air Force had been allocated two categories from which to choose names for their aircraft, ie birds and antelope. However, the SAAF applied to have its new upgraded Mirage III fighter renamed the Cheetah. The motivation for this choice was partly due to the fact that Armscor had given the aircraft that name during its production phase and, furthermore, the Air Force wanted the use of this name as it held a link with the famous 2 Squadron, better known as the Flying Cheetahs. ${ }^{36}$ It was therefore decided to allow the SAAF to use the proposed name with the proviso that this exception would not create a precedent. In the meantime, the SA Army had also applied to name its new armoured car the Cheetah. This application was in line with the suggested category for armoured vehicles, but was turned down in favour of the SAAF receiving the use of the word. The name Rooikat was then suggested to the Army instead, by the Military Information Bureau (MIB). The Army, however, passed over Rooikat in favour of the name Mamba. This too was denied as it had been decided to reserve snake names as a category for the SAMS (the name Rinkhals had already been reserved for a new ambulance). The reason for this decision was due to the symbolic link between the medical profession and snakes, which is embodied in the snake and staff emblem of the SAMS. It was thus felt that the SAMS had a certain claim upon a category pertaining to reptiles. Alternative names were then suggested and the Army eventually settled for
Caracal, only at the eleventh hour to change tack and decide that Rooikat was acceptable after all. ${ }^{37}$

Such incidents led to the realisation that the armaments nomenclature policy had to be centralised, structured and bound by rules. Chief of Staff Logistics was given the task of designing and finalising a policy, but before anything had been completed, the nomenclature portfolio was transferred from Chief of Staff Personnel to the MIB, known today as Documentation Service. The MIB in conjunction with the four arms of service rounded off a policy and issued it under a new directive, (C SADF Directive 2/7/84), on 1 Nov 1984 under the title "Naamgewing in die SAW", ${ }^{38}$ The new Directive was an attempt to fulfil the needs of the Defence Force as far as was possible. The new directive was concerned not only with armaments but also with the whole question of military nomenclature. The directive discussed was everything from street names to rifle names. While the Directive replaced the 1982 SADFO it nevertheless incorporated most of the important elements of its predecessor, and is a far more comprehensive policy statement. As far as the new armaments regulations were concerned, the Directive issued a full set of categories so that all of Armscor's products were incorporated. More importantly, it stated that all proposed products had to be named prior to them entering production in order to avoid nicknames being given to the products which then stuck and eventually usurped the official name. ${ }^{39}$ The 1984 directive also proposed guidelines for the naming of units, based upon the principles used in the past, and highlighted the policy for name provision inside military areas. Another important step was the coordination of military nomenclature from 1984 with nomenclature in civilian areas. In the case of street and military residential areas which fall outside military camps and bases, approval for proposed names now had to be gained from the Place Names Commit-

\footnotetext{
36 AMI/ARG 401/1/3/4, File : Logistic services, Name provision ofprojects, Enc 2. Minute dd 31 October 1985, SAAF HQ to Chief of Staff Logistics; and AMI/ARG 401/1/3/4, Enc 4, Minute dd 17 January 1985, SAAF HQ to the MIB, CSL.

AMI/ARG 401/1/3/4, File : Logistic Services - Name Provision of Projects.

C SADF Directive $2 / 7 / 84$, dd 1 November 1984, Naamgewing in die SA Weermag.

Col J.A. Combrinck and L. Jooste: Beleid van Naamgewing in die SAW (Annual of the Names Society SADF 1991), p.28,
} 
tee of the Department of National Education. Upon obtaining the required permission, the names then become listed as official place names in the Republic of South Africa. ${ }^{40}$

Although the C SADF Directive may appear to be very rigid in its control of military name provision, it has allowed for more flexibility and initiative than is at first realised. Applications for names outside of prescribed categories are always considered and approved if deemed suitable. In 1984 the nomenclature function of the Defence Force became the sole responsibility of Louise Jooste of SADF Documentation Services, who has updated the policy annually. Under her guidance the policy has matured into a comprehensive system allowing for pragmatism while, at the same time, maintaining uniformity and serving the needs of the Defence Force.

The 1980s may rightly be considered a decade of continuous growth and progress for the SADF. The period could also be viewed as a time in which name provision was at last laid down in a comprehensive and fixed policy. Ironically, just as nomenclature had been geared towards serving the needs of the larger self-sufficient SADF, the end of the decade brought noticeable cuts in Defence spending. The process of rationalisation which began in the late 1980s was due to two reasons, the termination of hostilities in $\mathrm{Na}$ mibia and secondly, in view of the worsening economic situation in South Africa. Notwithstanding these setbacks, name provision in the Defence Force continued to play an important role inside the Military and in the process, adapted itself towards the changing scenario in South Africa.

\section{THE SADF AND NAME PROVISION IN THE 1990S}

A current effort by the Defence Force to find and implement acceptable translations from English and Afrikaans into Black languages, is the most re- cent and notable change in the nomenclature policy of the SADF. The task is been carried out by the Directorate Language Services and is a natural result of the observation that the SADF will become increasingly multiracial in the future. ${ }^{41}$

The project is not as uncomplicated as it may seem as great care is required. Before Directorate Language Service was directly involved in nomenclature. the situation arose where in certain cases words were chosen from Black Languages to use as names for certain areas or items and have miscarried. For example a new SAMS ambulance came into service in 1987 and it was decided to name it the Mfezi which is the Zulu name for Rinkhals. There was some resistance to this name from outside the SAMS as another ambulance also used by the SAMS was named the Rinkhals. Despite the protestations, the Medical Service was insistent on using Mfezi and announced the arrival of the new ambulance via a press conference. Unfortunately for those who had supported the use of Mfezi, once the vehicle was put into service in the operational area it became a veritable white elephant in some cases as Black troops absolutely refused to be transported in the ambulance. ${ }^{42}$ It became apparent that the word Mfezi had negative and evil connotations which extended beyond the normal human fear of poisonous reptiles. Incidents such as these highlighted the need for language experts to be consulted. This is why Directorate Language Service began to play an important role in the nomenclature process. A further project has been launched by Directorate Language Services through which alternative names in Black languages are being provided and then advertised. It is hoped that programmes such as these will lead to increased understanding and communication between the different population groups in the SADF. ${ }^{43}$

On a more familiar front name provision continues to be needed in the De-

\footnotetext{
Col J.A. Combrinck and L. Jooste : Beleid van Naamgewing in die SAW (Annual of the Names Society SADF 1991), p.28. Maj D. Vorster : Naamgewing in Afrikatale in die SAW (Annual of the Names Society SADF 1991), pp.8-9.

42 AMI/ARG 502/2/1. File: Organisasie beheer benamings en herbenamings van hoofkwartiere en eenhede, Enc 10 , Minute dd 26 August 1987, SAMS Headquarters to Chief of Staff Intelligence.

43 Maj D. Vorster : Naamgewing in Afrikatale in die SAW (Annual of the Names Society SADF 1991), pp.8-9.
} 
fence Force and the policy still fulfils its regular role as the offical military nomenclature policy in South Africa.

\section{CONCLUSION}

South Africa has a heterogenous military culture which developed from a blend of French, Dutch, British and African influences. Over the years these influences have combined with the fighting traditions of the Boer Commandos and the spirit of the Settler volunteer regiments to form a unique military character. The nomenclature of the South African Defence Force reflects this rich and varied heritage.

Military name provision in the South African Defence Force is a relatively young tradition which was derived from a number of influences. Initially, name provision in the South African armed forces played an extremley understated role. The original name provision programme in this country, which barely even existed, was not specifically designed for the Union Defence Force, but was based upon the remnants of the name provision policy of the British Army. This unsatisfactory situation persisted for a very long time and only began to change when Advocate F.C. Erasmus became the Minister of Defence in 1948. Erasmus accorded name provision a degree of importance and designed a programme which lifted the portfolio to an official level for the first time. Due to the effort made to move away from the British tradition of military nomenclature. name provision in the SADF began to acquire a South African orientation towards the end of the 1950s. Following the first few years of official name provision the programme earned a certain amount of notoriety in some circles due to the manner in which it was used. Just as the policy had been too anglicised during pre-Nationalist rule it became a political tool under F.C. Erasmus.

This early beginning for military nomenclature in South Africa did not bode well for its future prospects. The nomenclature programme constantly appeared to be fraught with strife and had become politically tainted to a certain degree. In later years, however, it would emerge that the competition between the two language groups had unwittingly reached an equilibrium and fused together to form a unique South African tradition of military nomenclature.

The international isolation of South Africa which began towards the end of the 1960s had surpsingly positive effects on name provision in the SADF. One of the results of isolation was the growth of an indigenous arms industry, almost every armament which has ever been produced by Armscor was named by the South African Defence Force. Factors such as this have provided for a large degree of uniformity in the SADF nomenclature policy. Today, very few armed forces can claim that their nomenclature programmes reflect the military cultures of their countries better than the SADFs programme does.

The path along which military nomenclature in South Africa has developed, was laden with pitfalls, many of which had negative influences upon name provision during the tradition's formative years. Name provision was initially viewed as a necessary evil and it was relegated to an extremely minor role in the Defence Force. By contrast, in later years, nomenclature was perceived to be a convenient instrument of change and was used as such for a short period. Eventually name provision in the SADF was accorded a role in its own right and the value of the nomenclature programme gradually became appreciated. By the end of the 1980s, nomenclature in South Africa had evolved to the extent where it not only increased the esprit de corps of the Defence Force but, in addition, would be increasingly used as an aid to improve military communications and labour relations in the South African Defence arena.

* N.M. Cowling is attached to the Documentation Service, and administrates the SADF's Nomenclature portfolio. 